\title{
Vertical De-Integration in the Mutual Fund Industry: Using Knowledge as a Factor of Production
}

\author{
ABSTRACT \\ This paper extends the knowledge-based view of the firm by using relative \\ measures of two fundamental classifications of knowledge as factors of production. It \\ relates differences in relative quantities of these classifications of knowledge to the \\ probability that a given stage of production is outsourced or de-integrated. The probability \\ of de-integration of adjacent stages of production is found to increase on increasing reliance \\ on tacit knowledge and decreasing reliance on encapsulated knowledge. The research was \\ motivated by the belief that the cost and value of knowledge, as a factor of production, \\ influences economic efficiency.
}

\section{Keywords:}

Knowledge-Based View; Vertical Integration; Organizational Forms, Structure \& Design 


\section{KNOWLEDGE-BASED VERTICAL DE-INTEGRATION}

\section{INTRODUCTION}

We often find diversity when examining whether adjacent stages of production are separated by inter-firm boundaries in any given industry in developed economies. An examination of the Canadian mutual fund industry, for example, finds that about four-fifths of all mutual funds use in-house portfolio managers, but about one-fifth use the portfolio management services of sub-advisors external to the mutual fund management firm - a level of de-integration similar to that found in the mutual fund industries of other developed economies. This paper provides evidence using a knowledge-based view of the firm (KBV) that suggests that differences in the types of knowledge used in production may explain the contemporaneous existence of integrated and de-integrated organizational structures in an industry.

This study responds to the challenge of optimizing firm boundary location by “applying an economic calculus to knowledge" (Simon, 1999, p. 34). If differences in cost and technical efficiency of knowledge-based factors of production are a function of specialization over time, as suggested by Demsetz (1988), then in efficient markets, one would expect these different costs and technical efficiencies to be manifested as differences in proportions of knowledge-based factors used in various stages of production. These differences in relative reliance on distinct knowledge-based factors of production may also be expected to affect the location of inter-firm boundaries. Put another way, this paper addresses a fundamental KBV question.

Do differences in knowledge-based factors of production explain the presence or absence of inter-firm boundaries? 


\section{KNOWLEDGE-BASED VERTICAL DE-INTEGRATION}

Jensen and Meckling (1996) stress that to optimize decision-making, it is important that decision authority and relevant knowledge be co-located. They further suggest that the distribution of decision-making rights in the economy reflects the limitations of individuals' knowledge (Jensen, Meckling, 1996). In other words, organizational structures in a competitive environment are constructed to economize on the deployment of pertinent knowledge among various actors. Since the mutual fund industry is competitive, it is reasonable to assume that organizational structures found in the industry exist because they represent the economic distribution of knowledge (but this remains to be tested). The notion that firm boundaries are found to economize on knowledge-based factors of production sets the context for this paper.

The question of firm boundary location is important since it attempts to establish which productive activities a firm should undertake in-house, which products it should purchase or activities it should outsource, and when it should sell its product to the next segment of the value chain (Demsetz, 1988). Firms continually decide whether to abandon a process currently performed in-house to upstream or downstream firms and whether to extend into upstream or downstream activities.

\section{THEORETICAL BACKGROUND}

Much of the evidence relating vertical integration to profitability is based on concepts grouped under the general heading of transaction cost economics (TCE), a concept introduced by Coase (1937) and later elaborated by Williamson (1975, $\underline{1979}, \underline{1981})$ and others. Evidence based on TCE theory suggests that vertical integration may lead to enhanced firm performance by reducing switching costs (Monteverde, Teece, 1982), enhancing monitoring of sales forces (Anderson, 1985), protecting relationship-specific 


\section{KNOWLEDGE-BASED VERTICAL DE-INTEGRATION}

investments (Joskow, 1987), and reducing small numbers bargaining and intellectual property rights expropriation hazards (Pisano, 1990).

On the other hand, there is also evidence that de-integrating for production purposes may enhance firm performance. This evidence counters a possible over-emphasis on transaction cost avoidance as motivation for vertical integration. Threats of technological uncertainty and obsolescence in industries with many participants, argue against integration (Balakrishnan, Wernerfelt, 1986). Research also suggests that firms more capable at measuring innovation performance will prefer alliances over integration (Robertson, Gatignon, 1998), and those with strong technological capabilities may de-integrate even in the face of ex-post contract renegotiation hazards (Mayer, Salomon, 2006). While TCE is said to subsume economizing on production costs (Williamson, 1979), empirical research has generally focused on economizing on transaction costs and assumed the absence of differential production costs (Langlois, Foss, 1999) (for exceptions, see Hoetker, 2006;

Mayer, Salomon, 2006; Walker, Weber, 1984).

\section{Production}

One perspective that has lacked significant attention has been the examination of vertical integration or de-integration in terms of economic efficiency of combining different quantities of distinct knowledge-based factors of production. Assuming differences in comparative advantages between firms in the application and generation of economically valuable knowledge, it would seem logical to locate firm boundaries so as to take advantage of these differences.

"Because it is uneconomical to educate persons in one industry in the detailed knowledge used in another, recourse is had to developing or encapsulating this knowledge 


\section{KNOWLEDGE-BASED VERTICAL DE-INTEGRATION}

into products or services that can be transferred between firms cheaply because the instructions needed to use them do not require in-depth knowledge about how they are produced... A production process reaches the stage of yielding a saleable product when downstream users can work with, or consume, the 'product' without themselves being knowledgeable about its production" (Demsetz, 1988, p. 159).

"A single firm works a product into new, simpler-to-use... products until the diversity of uses further downstream is so great as to require this firm... to bear greater costs of information acquisition and maintenance that are avoided by potential users... Title to 'the' product is likely to change hands when this point in the development of product... is reached... The boundary defining degree of vertical integration will have been established (Demsetz, 1988, p. 160)".

\section{Specialization}

Firms, as well as individuals, specialize in the knowledge they apply in production. Continuous specialization intensifies comparative advantages, which in turn, promotes even more specialization in the generation of various "shapes" of knowledge (Simon, 1999). Differences between classifications of knowledge are therefore elemental to a comprehensive knowledge-based view of the firm.

Demsetz $(1988,1991)$ considers firms to be knowledge storage units and suggests that firms can enhance their potential by specializing in the acquisition of knowledge. It is economical for firms to specialize because it is expensive to generate, preserve, and exploit knowledge (Demsetz, 1988). Knowledge specialization by firms manifests itself in a constructive cycle of human-capital reinforcement, further specialization of labour, and 


\section{KNOWLEDGE-BASED VERTICAL DE-INTEGRATION}

improvement in economically efficient production (Becker, Murphy, 1992; Demsetz, 1988, 1991; Grant, 2002).

Grant (2002) also argues that specialization of knowledge defines the firm. First, the knowledge applied within a firm for production is more specialized than the knowledge required in utilizing the firm's products. Secondly, firms provide the organizational environment within which the specialized knowledge of individuals can be integrated (Grant, 2002).

\section{Vertical Integration and De-integration}

Along a given value chain, firms may benefit from specialization by focusing on the stage(s) of production in which they have a comparative advantage, and exiting from those stages in which they have a comparative disadvantage. When a market interface (inter-firm boundary) exits between two stages of production, firms will generally select their position either upstream or downstream of the boundary so as to maximize their productive efficiencies (Demsetz, 1988; Jacobides, Hitt, 2005; Pfaffmann, 1998, 2000).

A market interface in a value chain does not obviate the need from some knowledge overlap as the firms on either side of the inter-firm boundary will be engaged in some complementary tasks simply by virtue of their adjacency in the value chain (Pfaffmann, 2000). However, these firms will derive their comparative advantage from productive activities based on dissimilar tasks rooted in their specialized knowledge.

Integrating adjacent stages of production that differ significantly in their specialized knowledge could lead to managerial diseconomies of scope (Jacobides, Hitt, 2005; Lawrence, Lorsch, 1967). Productivity in each of the adjacent stages could be constrained if, for example, common management practices (Prahalad, Bettis, 1986), or a single 


\section{KNOWLEDGE-BASED VERTICAL DE-INTEGRATION}

technological paradigm and trajectory (Dosi, 1982), were applied to both stages. Deintegrating the adjacent stages in those cases, and applying a more focused management on each stage, could enhance overall productivity (Jacobides, Hitt, 2005).

A knowledge-based productivity explanation may dominate traditional transaction cost economic (TCE) theory in explaining inter-firm boundaries. In research conducted by Argyres (1996), evidence suggested that firms outsource, or de-integrate from, those stages of production in which they have a comparative disadvantage in capabilities. He found an inter-firm boundary between a tacit-knowledge-based mold-making stage and a more formalized-knowledge-based design engineering stage (Argyres, 1996). While deintegration of the two adjacent stages of production may be explained from a knowledgebased productivity perspective, it runs contrary to the TCE theory that suggests integration of the two stages based on the high physical asset specificity of customized molds (Argyres, 1996).

This paper provides further evidence that differences in relative reliance on fundamentally different knowledge-based factors of production may be instructive in the location of inter-firm boundaries. The unit of analysis in this study is the boundary between mutual fund management firms and the portfolio managers who manage individual mutual funds. A given mutual fund is considered integrated if its portfolio manager(s) are employees of the mutual fund management firm or an affiliated firm, and is considered deintegrated if a firm independent of the mutual fund management firm employs the portfolio manager.

\section{Analytical intensity of complex security valuation}




\section{KNOWLEDGE-BASED VERTICAL DE-INTEGRATION}

Definition of a mutual fund. The Securities Act of Ontario is the legislation that governs the bulk of the mutual fund industry in Canada since the industry is centered in Toronto, Ontario, and securities legislation currently falls under provincial jurisdiction. This act defines a mutual fund, with some exceptions, as an issuer whose primary purpose is to invest money provided by its security holders, and whose securities entitle the holder to receive on demand a proportionate interest in the value of the fund's net assets. In the same act, an issuer is defined as "a person or company who has outstanding, issues or proposes to issue, a security" (Securities Act, 2007).

A mutual fund is an "open-ended" investment fund, which means that investors can contribute money to the fund at any time as well as redeem their units or shares to the fund at any time. When units or shares of a mutual fund are redeemed the investor receives an amount of money based on the current market value of the fund s portfolio. Fund managers charge fees, based on the value of the fund's assets, for administering the fund and compensating the various service providers in the value chain. These service providers include portfolio managers who are contracted by mutual fund management firms to make securities selection decisions. Mutual fund management firms charge fees to their unit holders (or shareholders), based on the value of a fund's assets and the analytical complexity of portfolio management, for administering a mutual funds and managing its investment portfolio (Khorana et al., 2009; Tufano, Sevick, 1997).

Security valuation. Cashman and Deli (2009) found evidence suggesting that portfolio management requiring greater analytical intensity due to complex security valuation was positively correlated with the probability of de-integration between fund administration and portfolio management. Valuation of foreign equity, for example, is 


\section{KNOWLEDGE-BASED VERTICAL DE-INTEGRATION}

considered more complex than the valuation of domestic equity. While domestic equity valuation requires an estimation of future cash flows and appropriate discount rates, foreign equity valuation also demands an understanding of differences in the cultural, business, legal, and tax environments and how these affect valuation (Cashman, Deli, 2009). With foreign equity funds, portfolio managers must consider the degree and direction of foreign exchange rates, political, legal, and socio-economic environments that are different from more familiar domestic ones, as well as different and perhaps less meticulous financial reporting frameworks that are often incommensurable with better known domestic regulatory systems. Even where these differences are minimal, changes in the value of a foreign currency over the investment holding-period is one variable involved in the valuation of foreign equity that is not a consideration with a domestic equity investment. Similarly, because equity may be considered a residual claim on assets and generally involves greater risk than debt, Cashman and Deli (2009) suggest that, on average, the valuation of equity is more complex than the valuation of debt. They allow however that this may not always be the case when, for example, comparing the equity of a large regulated firm with the debt of a small distressed firm (Cashman, Deli, 2009).

Valuation of a financial security whose value is influenced by a greater number of interrelated variables will be more complex and therefore more analytically intense than valuation of a security with a few discrete estimation elements. The valuation of foreign equities may be considered more analytically intense than the valuation of domestic equities, because the former is performed with relatively more ambiguous data drawn from a more opaque socio-economic environment, while the latter relies on relatively unambiguous data drawn from a less obscure domestic market. 


\section{KNOWLEDGE-BASED VERTICAL DE-INTEGRATION}

The valuation of fixed income securities is similarly less analytically intense than the valuation of domestic equities. With fixed income securities, such as bonds and debentures, the amount, timing and duration of cash flows are prearranged by agreement between borrower and lender. The greatest risk to mispricing stems from misjudging changes in the general level of interest rates (interest rate risk). Additional risks associated with pricing of fixed income securities are associated with expectations of inflation and the credit rating of the issuer. Analysts will not differ practically from each other in the valuation of fixed income securities, despite some differences in technique (Cottle et al., 1988).

In contrast, the analysis of contingent, intermittent and irregular cash flows accruing to equity securities is more complex. In addition to changing interest and inflation rates and issuer credit-worthiness, a portfolio manager must also consider how macro-economic factors such as the unemployment rates, consumer and producer sentiments, affect the contingent cash flows generated by equity securities generally, and how a firm's management, competitive advantages, competitors, and markets affect the value of its equity in particular. These variables are rarely the focal point of those analyzing debt securities.

Analytical intensity and reliance on tacit knowledge. Analytical intensity has been variously defined as comprehensiveness, procedural rationality, or extent of analysis (Kahlert, 2010; Miller, 2008). Comprehensiveness refers to the degree to which an extensive decision-making process, involving high levels of investigatory activity, is utilized to screen and evaluate alternatives (Miller, 2008). In complex decision-making conditions, comprehensiveness helps ensure consequential variables are investigated, 


\section{KNOWLEDGE-BASED VERTICAL DE-INTEGRATION}

resulting in more accurate perceptions and better outcomes than if such comprehensiveness was absent (Dean, Sharfman, 1996; Miller, 2008). Similarly, Dean and Sharfman (1996, p. 373) define procedural rationality as "the extent to which the decision process involves the collection of information relevant to the decision and the reliance upon analysis of this information in making the choice”. Finally, Miller (2008) describes extensive approaches to analysis as those that incorporate high levels of examination targeted at developing a diverse criteria for filtering alternatives and evaluating them.

These descriptions of analytical intensity suggest that relative reliance on tacit knowledge will increase on increasing complexity of decision-making. Tacit knowledge may be defined as a value-endowing meta-resource originating from thought, reflection, or experience, and held by a knowing agent (Boisot, 1998; Choo, Bontis, 2002; Polanyi, 1969; Spender, 1996; van den Berg, 2013). This definition does not contradict the concept of dispersed knowledge, the idea that no single knowing agent is omniscient, but rather aims to put forward tacit knowledge as a factor of production.

Tacit knowledge is employed in judging, interpreting, framing and solving problems (Balconi et al., 2007). It is used by individuals to evaluate information, to conceive of difficult to foresee outcomes, and to establish novel correlations among variables and give meaning to them (Balconi et al., 2007). Tacit knowledge includes "non-specific analytical skills for the recognition, formulation and solution of complex problems..." with "strong evaluative elements... based on experience" (Zellner, 2003, p. 1884). An individual's heuristic and interpretive skills used in decoding and interpreting information are tacit in nature (Balconi, 2002). Successful performance with greater complexity of security valuation ("the imperfectly known interplay of many variables") demands greater analytical 


\section{KNOWLEDGE-BASED VERTICAL DE-INTEGRATION}

intensity and therefore suggests greater reliance on tacit knowledge (Balconi, 2002, p. 362).

Conversely, given less complexity and analytical intensity in the valuation of domestic fixed income securities relative to valuation of foreign equity securities, success may be less reliant on tacit knowledge. Instead, valuation of less analytically intense securities may rely relatively more on the application of encapsulated knowledge.

Encapsulated knowledge may be defined as a value-endowing meta-resource in the form of knowledge embedded in an artefact's design and functionality (Boisot, 1998; Gorga, 2007; Langlois, 2001; van den Berg, 2013). Thus, the less complex and analytically intense valuation of domestic fixed income securities may be relatively more reliant on knowledge embedded, for example, in the design and functionality of software platforms, than on the tacit knowledge resident only in the minds of portfolio managers.

\section{HYPOTHESES}

\section{Integration / De-Integration Profile}

Cashman and Deli (2009) found that U.S. mutual funds invested primarily in foreign equity had a greater probability of being de-integrated than those invested primarily in domestic equity, which in turn had a greater probability of being de-integrated than those invested primarily in fixed income securities. Tests were first conducted to determine whether the sample of Canadian mutual funds in this study shared a similar integration/deintegration profile.

Evidence from all sampled mutual funds identified as foreign equity or domestic equity, suggests that foreign equity mutual fund have a greater probability of being managed by de-integrated portfolio managers than domestic equity mutual funds $(p<$ 


\section{KNOWLEDGE-BASED VERTICAL DE-INTEGRATION}

0.001), corroborating Cashman and Deli (2009). Table 1 presents the results.

Insert Table 1 about here

Similarly, evidence from sampled all mutual funds identified as domestic equity or fixed income, suggests that domestic equity mutual funds have a greater probability of being managed by de-integrated portfolio managers than fixed income mutual funds $(\mathrm{p}<$ 0.001), again corroborating Cashman and Deli (2009). Table 2 presents the results.

Insert Table 2 about here

\section{Analytical Intensity and Divergent Knowledge Reliance}

Cashman and Deli (2009) argued that "security pricing is most difficult (analytically intensive)" with foreign equity funds and easiest with fixed income funds. They further argued that "when security valuation is complex, it is more difficult to effectively transfer the relevant knowledge required to understand a value recommendation" and that this accounts for the pattern of de-integration observed in the mutual fund industry (Cashman, Deli, 2009, p. 649). Since difficulty of effective transfer of knowledge is an increasing function of its tacitness (Szulanski, 1996; von Hippel, 1994; Zander, Kogut, 1995), we would expect to observe that differences in analytical intensity in the valuation of securities are positively related to reliance on tacit knowledge (and negatively related to reliance on encapsulated knowledge). The following hypotheses were tested were conducted on mutual funds broadly categorized as foreign equity, domestic equity, and fixed income to detect whether reliance on tacit and encapsulated knowledge is related to differences in analytical intensity of security valuation. 


\section{KNOWLEDGE-BASED VERTICAL DE-INTEGRATION}

H1: Relative reliance on tacit knowledge by portfolio managers managing foreign equity mutual funds is greater than that for managing domestic equity mutual funds.

H2: Relative reliance on encapsulated knowledge by portfolio managers managing foreign equity mutual funds is less than that for managing domestic equity mutual funds.

Similarly, to detect whether evidence for a similar distinction between reliance on tacit and encapsulated knowledge is also present between domestic equity and fixed income mutual funds, the following hypotheses was tested.

H3: Relative reliance on tacit knowledge by portfolio managers managing domestic equity mutual funds is greater than that for managing fixed income mutual funds.

H4: Relative reliance on encapsulated knowledge by portfolio managers managing domestic equity mutual funds is less than that for managing fixed income mutual funds.

Finally, to examine the impact of control variables, and as a robustness check, two logistic regressions were performed to test the following hypothesis.

H5: The probability of de-integration of a mutual fund is related to the portfolio manager's relative reliance on tacit, and encapsulated knowledge.

The probability of de-integration of a mutual fund may be moderated by a number of variables. Mutual fund management firms may, for example, believe that their in-house portfolio management capability is limited in foreign securities, or limited in less traditional hedge funds or synthetic funds, and therefore contract for the necessary skills from external portfolio managers.

\section{DATA AND METHODS}




\section{KNOWLEDGE-BASED VERTICAL DE-INTEGRATION}

\section{Research Population}

The population for this research consists of Canadian mutual funds and their portfolio managers. Portfolio managers are also referred to as portfolio advisors, especially when they are employed by a sub-advisory firm not related to the mutual fund management firm. Mutual funds and their portfolio managers are an appropriate population for this research for a number of reasons. First, while in-house portfolio managers manage the majority of mutual funds, there is a significant and growing trend towards vertical deintegration, known in the industry as making use of sub-advisory services (Costello, 1999; Duong, 2010; O'Brien, 2001). The extent of vertical de-integration is heterogeneous among the various mutual fund asset classes, with some, such as money market funds rarely being sub-advised, while about half of the assets in specialty health mutual funds are sub-advised in Canada and the US. The presence of both integrated and de-integrated mutual funds provides an opportunity to examine how the nature of knowledge may inform the decision to integrate, or de-integrate, the portfolio management function. ${ }^{1}$

Second, the capital markets industry is relatively knowledge-based with relatively little physical capital involved in the various productive activities undertaken. This trend to dematerialization appears to be continuing as evidenced by various reports of the Canadian Capital Markets Association (CMA). The CMA has suggested that further dematerialization would reduce significant inefficiencies for the industry. Some mutual fund web sites indicate that paper-based certificates of ownership of a security are no

\footnotetext{
${ }^{1}$ Determining the motivation for outsourcing the portfolio management function was beyond the scope of this paper. One CEO offered that his mutual management firm outsourced to fill out his firm's offerings when a new variety of product suddenly appeared in demand and in-house capability did not yet exist. At least one other mutual fund management firm outsourced all of its portfolio management, claiming that its expertise lay not in portfolio management but in the selection of exceptionally well-performing portfolio managers.
} 


\section{KNOWLEDGE-BASED VERTICAL DE-INTEGRATION}

longer being available but have been replaced by digital certificates. Consequently, the research results in the mutual fund industry are expected to be more robust than if a more material-based manufacturing industry were examined.

\section{Sample and Data}

Data were collected from two sources, one primary and one secondary. Primary data were collected from portfolio managers using an Internet based survey. The data were collected from mid-2006 into the first quarter of 2007. Collection of items designed to measure relative reliance on tacit, codified and encapsulated knowledge necessitated the use of survey, as no secondary source of such data is available.

Measures of relative reliance by portfolio managers on tacit and encapsulated knowledge were calculated for 430 mutual funds. Of these funds, 311 fell into the broad categories of foreign equity, domestic equity, and fixed income. The remaining mutual funds that did not fit into one of these three broad categories consisted mainly of balanced and specialty funds. The 311 mutual funds were divided into 117 foreign equity funds, 120 domestic equity funds, and 74 fixed income funds.

Secondary Data. Secondary data were provided by Fundata Canada Inc., which agreed to provide its data at no cost for academic purposes. The secondary data consisted of individual mutual fund details, including particulars about mutual fund management firms and individual portfolio managers. The secondary data facilitated the detection of inter-firm boundaries between mutual fund management firms and portfolio management firms.

Primary Data. Sampling within all firms was not random. A few of the firms agreeing to participate required the negotiation of a 'representative' list of potential respondents because the senior executives would only agree to the surveying of a limited 


\section{KNOWLEDGE-BASED VERTICAL DE-INTEGRATION}

number of his or her portfolio managers. The criteria employed by these senior executives were not revealed.

A total of 252 invitational emails were sent to portfolio managers in the 21 firms. The overall response rate was $60.7 \%$ (152). This excellent response rate is tempered by the reality that not all potential firm employees were available to be sampled and only $22 \%$ of the invited firms participated. Nevertheless, the response rate compares favorably with the overall response rate of $6.3 \%$ achieved in a recent survey of portfolio managers in the USA (Farnsworth, Taylor, 2006).

Survey. The online survey consisted primarily of six questions (available from the author upon request) designed to capture relative reliance on tacit, codified, and encapsulated knowledge. Each question related the three classifications to one of the six perspectives: locus, transferability, expression, acquisition, source of value, and observability (van den Berg, 2011, 2013). The questions were designed to elicit relative measures of reliance on each form of knowledge in the production and management of a mutual fund portfolio.

Portfolio managers were asked to rate the most important knowledge-based factor with a value of 10 and to rate the remaining two items relative to 10 (and to each other) for each of the six perspectives. The respondent ratings for reliance on the three classifications of knowledge were therefore relative measures. These were later transformed to sum to one, resulting in a total of 18 items measuring relative reliance on one of three classifications of knowledge across six perspectives.

Before the ratio variables were standardized, they were reviewed for normality, which could have been impaired by skewness and/or kurtosis. After five transformations, 


\section{KNOWLEDGE-BASED VERTICAL DE-INTEGRATION}

based on recommendations gleaned from 'laddering' (StataCorp, 2005), 18 items were standardized. Selected standardized items were then averaged to produce three scales or indexes measuring relative reliance on tacit, codified, and encapsulated knowledge. A number of validity tests were performed, including confirmatory factor analysis, and structural equation modeling. Both the scale reliability tests and the confirmatory factor analysis failed to produce a reliably measurable latent variable of reliance on codified knowledge $($ Cronbach's alpha $=0.58)$. Accordingly, all subsequent tests and modeling were performed exclusive of relative reliance on codified knowledge.

\section{Variables and Measurement}

Dependent Variable: The Probability of Vertical De-integration. The research sought an explanation for the observation that the portfolio manager role was integrated within a mutual fund management firm in the majority of cases, but de-integrated (performed in a separate firm) in other cases. A mutual fund may be termed to be 'subadvised' when an individual from an organization outside the mutual fund management firm is contracted to act as portfolio manager. The term 'sub-advised' is used by the industry to describe such an arrangement rather than simply 'advised' because the fund management firm retains ultimate legal responsibility for managing the mutual fund, and is responsible for monitoring the portfolio manager on behalf of the mutual fund's unit holders. When a mutual fund is sub-advised, the mutual fund management firm is legally required to notify investors through the fund's prospectus.

For the purposes of this research, however, not all mutual funds whose prospectuses report that they are sub-advised are considered de-integrated. For example, the prospectus of a mutual fund may indicate that CIBC is the mutual fund management firm, its 


\section{KNOWLEDGE-BASED VERTICAL DE-INTEGRATION}

subsidiary CIBC Asset Management Inc. is the portfolio manager, and TAL Global Asset Management Inc. is the fund's 'sub-adviser'. For the purposes of this research, the mutual fund would not be considered to be de-integrated since TAL is a wholly owned subsidiary of CIBC. In other words, a mutual fund management firm and a portfolio management organization are only considered de-integrated when the individual that acts as portfolio manager is not an employee of the mutual fund management firm or any other firm known to be owner-affiliated with the management firm. This definition corresponds to that used by at least one other research organization studying sub-advisory services (Financial Research Corporation).

Independent Variables. Only in a few exceptional situations will production not rely upon some combination of tacit, codified, and encapsulated knowledge. In the vast majority of cases, a mixture of all three knowledge-based factors will contribute to production. The independent variables of interest in this research are two knowledge-based factors of production defined as relative reliance on tacit knowledge and relative reliance on encapsulated knowledge.

Control Variables. In addition to reliance on knowledge-based factors of production, the probability of de-integration of a mutual fund may be moderated by a number of variables. Mutual fund management firms may, for example, believe that their in-house portfolio management capability is limited in foreign securities, or limited in less traditional hedge funds or synthetic funds, and therefore contract for the necessary skills from external portfolio managers. 


\section{KNOWLEDGE-BASED VERTICAL DE-INTEGRATION}

Control variables considered in this study included hedge-fund status, synthetic fund status, as well as variables for each of seven specific investment regions ${ }^{2}$ (Canada, USA, North America, Europe, Japan, International, and Global). Also used for control was a multinomial variable based on Cashman and Deli (2009), that was split into two binomial variables: Foreign Equity relative to Fixed Income, and Domestic Equity relative to Fixed Income.

One control variable that was not included was fund family size. Cashman and Deli found that smaller mutual fund management firms were more likely to engage sub-advisory services to realize economies of scale. They also found that fund family size was not significant in explaining mutual fund performance.

\section{Analysis}

All mutual funds have portfolio managers. Some mutual funds have multiple portfolio managers (multi-managed) and some only have one (single-managed). Some portfolio managers are involved in the management of only one mutual fund and some are involved in the management of a number of mutual funds. Every combination of mutual fund to portfolio manager relationship exists (one-to-one, one-to-many, many-to-one, and many-to-many). In other words, one mutual fund may have one portfolio manager or more than one portfolio manager, and a collection of mutual funds may be managed by a single portfolio manager, or by a group or team of portfolio managers. Each of these relationships may consist of portfolio managers whose firm is affiliated, or not, with the fund management firm. In the case of multi-managed funds, the fund management organization

\footnotetext{
${ }^{2}$ The global investment region characterizes mutual funds whose portfolios may include securities from anywhere in the world, while the international investment region characterizes mutual funds whose portfolios are invested outside of Canada and the USA.
} 


\section{KNOWLEDGE-BASED VERTICAL DE-INTEGRATION}

may be affiliated with all, none, or some of the portfolio managers' firms. Since the research attempts to explain the presence or absence of discrete inter-firm boundaries, the cases involving multi-managed funds with mixed affiliation were excluded.

Of the 147 portfolio managers who responded to the survey, 87 could be identified as individual portfolio managers in the secondary mutual fund data. The remaining 60 were likely included in the secondary data as part of a 'team' of portfolio managers.

Unfortunately, there was no definitive method of learning the identities of the individuals constituting each team for the various periods under evaluation. The 87 individual portfolio managers were found in 619 relationships with mutual funds or about seven mutual funds for each portfolio manager.

The distribution of relationships is skewed with a few portfolio managers being related to a large number of mutual funds. It appears that these portfolio managers manage many essentially identical funds. These 'clone' funds are simply 'white label' products rebranded for sale by a variety of mutual fund management firms and/or distributors. It is also possible that some portfolio managers, if they have a good reputation, are assigned for marketing purposes to multi-managed mutual funds to lend credibility to otherwise unfamiliar teams. Being spread over an exceptionally large number of mutual funds probably limits their influence on the performance of each individual mutual fund.

The measurements for relative reliance on tacit and encapsulated knowledge of the 87 identifiable portfolio managers were added to the database of 5,811 mutual funds, as applicable. For the 171 single-managed relationships, the measurements of the knowledgebased variables were entered on a one-to-one basis (i.e., the measurements from a single 


\section{KNOWLEDGE-BASED VERTICAL DE-INTEGRATION}

portfolio manager were added to the one mutual fund for which that portfolio manager was identified).

The 619 portfolio management relationships were with 430 individual mutual funds, 319 of which had portfolio managers who were considered integrated and 111 of which were considered de-integrated. The larger percentage of integrated mutual funds was similar to the distribution of all 3,856 mutual funds for which both organizational structure and management mode were known. A chi-square test was conducted to analyze whether or not the relationship between organizational structure and management mode previously tested with the 3,856 mutual funds was also significant with the subset of 430 for which measures of relative reliance on tacit and encapsulated knowledge had been estimated. The results were significant $(\mathrm{p}<0.01)$ indicating that the null hypothesis of independence may be ruled out, and that organizational structure and management mode variables are also significantly related for this subset. Table 3 presents the distribution.

Insert Table 3 about here

\section{Specification of the Model}

The dependent variable is the presence or absence of an inter-firm boundary between a mutual fund management firm and a portfolio manager, a binary variable indicating whether an upstream stage of production and an adjacent downstream stage of a value chain are integrated in one firm or de-integrated into two separate and unaffiliated firms.

Some adjacent stages of production may be separated by a less than definitive interfirm boundary. For example, a downstream stage (a mutual fund distributor) may have an 


\section{KNOWLEDGE-BASED VERTICAL DE-INTEGRATION}

investment interest in an upstream stage (a portfolio management firm) of greater than $0 \%$ but less than $100 \%$, and vice versa. For the purposes of this research, stages of production will be considered de-integrated when they share no ownership in common. Any evidence of common ownership, even if only partial, will be considered as evidence of integration. In practice however, there is no public record of ownership below $10 \%$, so the actual demarcation is at that level.

\section{RESULTS}

\section{Analytical intensity of complex security valuation}

If greater analytical intensity may be manifested as greater reliance on tacit knowledge and lesser reliance on encapsulated knowledge (Balconi, 2002; Balconi et al., 2007), then in accordance with Cashman and Deli (2009), portfolio managers managing foreign equity mutual funds are more reliant on tacit knowledge than portfolio managers managing domestic equity mutual funds. Testing of $\mathrm{H} 1$ provided support for the relationship $(\mathrm{p}<0.001)$. Cohen's 'd' was calculated to be 0.71 (Cohen, 1992) for the effect size of the difference between relative reliance on tacit knowledge for foreign equity mutual funds and domestic equity mutual funds. This may be interpreted as a medium-tolarge effect size (Cohen, 1988). The power of the test was calculated to be $98 \%$ (Faul et al., 2007, 2007) when alpha was set at 0.001 (two-tailed).

Testing of $\mathrm{H} 2$ also provided support for a relationship between relative reliance on encapsulated knowledge and the portfolio management of foreign equity mutual funds and domestic equity mutual funds. Evidence suggests portfolio managers managing foreign equity mutual funds are less reliant on encapsulated knowledge than those managing domestic equity mutual funds $(\mathrm{p}<0.001)$. Table 4 presents the results. 


\section{KNOWLEDGE-BASED VERTICAL DE-INTEGRATION}

Insert Table 4 about here

$\mathrm{H} 3$ and $\mathrm{H} 4$ were tested to detect whether or not similar evidence is also present between domestic equity and fixed income mutual funds. $\mathrm{H} 3$ and $\mathrm{H} 4$ were both supported. Evidence suggests portfolio managers managing domestic equity mutual funds are more reliant on tacit knowledge than portfolio managers managing fixed income mutual funds ( $\mathrm{p}$ $<0.001)$. Evidence also suggests portfolio managers managing domestic equity mutual funds are less reliant on encapsulated knowledge than those managing fixed income mutual funds $(\mathrm{p}<0.001)$. Table 5 presents the results.

Insert Table 5 about here

\section{De-integration and knowledge-based factors of production}

The results of testing $\mathrm{H} 1$ through $\mathrm{H} 4$ suggest that the analytical intensity of security valuation put forth by Cashman and Deli (2009) as a cause of de-integration may be positively related to reliance on tacit knowledge and negatively related to reliance on encapsulated knowledge. These results taken together also appear to suggest that increasing analytic intensity of complex security valuation as revealed by increasing (decreasing)

relative reliance on tacit (encapsulated) knowledge gives rise to an increasing probability of de-integration and the presence of an inter-firm boundary. Figure 1 depicts a graphical summary of these findings.

The size and labels of the spheres represent the probability of de-integration. The scale of both axes is in units of standard deviation. 


\section{KNOWLEDGE-BASED VERTICAL DE-INTEGRATION}

Insert Figure 1 about here

Two logistic regressions were used with organizational structure (probability of deintegration) as the dependent variable to test H5. The first test consisted of a logistic regression incorporating moderating effects from hedge-fund status, synthetic fund status, and investment region. Dummy variables were used for each of seven investment regions ${ }^{3}$ (Canada, USA, North America, Europe, Japan, International, and Global), hedge fund status, and synthetic fund status. The results of the first stage model suggest that whether a mutual fund is a hedge fund or a synthetic fund $(p>0.5)$, does not impact the probability that it will be de-integrated. There is evidence, however, that suggests three of the seven investment regions influence the probability of de-integration with some degree of significance. Model I in Table 6 displays the estimated coefficients for only those three investment regions. The specific investment regions that were eventually found to be significant were Canada $(p=0.013)$, Europe $(p<0.001)$, and Global $(p=0.006)$, but Canada only became significant once the knowledge-based variables were added in Model II. The coefficients for Europe and Global (foreign) are larger than the coefficient for Canada (domestic) supporting the findings of Cashman and Deli (2009). The positive coefficient estimates for each of the variables suggest that the probability of de-integration increases for mutual funds invested in any of these regions.

In Model II, the variables for relative reliance on tacit and encapsulated knowledge were added to the variables used in Model I. The estimate for relative reliance on

\footnotetext{
${ }^{3}$ The global investment region characterizes mutual funds whose portfolios may include securities from anywhere in the world, while the international investment region characterizes mutual funds whose portfolios are invested outside of Canada and the USA.
} 


\section{KNOWLEDGE-BASED VERTICAL DE-INTEGRATION}

encapsulated knowledge was significant $(p<0.001)$. The co-efficient for the relative reliance on tacit knowledge, while surprisingly negative, was not significant $(p>0.10)$. The significant positive coefficients for investment regions of Europe, and Global may capture the effect of relative reliance on tacit knowledge. Model II in Table 6 displays the estimated coefficients for all significant variables plus relative reliance on tacit knowledge. The improvement in the $-2 \log$ likelihood from Model I to Model II was significant $(p<0.001)$

Insert Table 6 about here

The second test of H5 was a logistic regression that directly tested whether relative reliance on tacit knowledge may be used as a measure of analytic intensity in security valuation as suggested by Cashman and Deli (2009). The test consisted of a logistic regression using a multinomial variable for the categories of Foreign Equity, Domestic Equity, and Fixed Income.

The results in Model III support the findings of Cashman and Deli (2009) that Foreign Equity mutual funds are more likely de-integrated than Fixed Income funds. The variable of Foreign Equity to Fixed Income is significant in explaining the probability of de-integration, while that of Domestic Equity to Fixed income appears insignificant.

Model IV expands on Model III by including the variable of relative reliance on tacit knowledge by portfolio managers. The model suggests that greater analytic intensity in security valuation is exhibited in this research as greater relative reliance on tacit knowledge. The addition of the significant tacit knowledge variable is the only difference between Model III and Model IV, and its introduction causes the Foreign Equity relative to 


\section{KNOWLEDGE-BASED VERTICAL DE-INTEGRATION}

Fixed Income variable to loose its significance. The improvement in -2 log likelihood is significant $(p<0.01)$. The results are displayed in Table 7.

Two alternatives to Model iV were also tested. One alternative added the variable of relative reliance on encapsulated knowledge, while the other alternative simply replaced the relative reliance on tacit knowledge with relative reliance on encapsulated knowledge. With both alternatives, the Foreign Equity relative to Fixed Income coefficient still became insignificant.

Insert Table 7 about here

\section{Conclusion}

Two conclusions may be drawn from this research. First, differences in relative reliance on tacit and encapsulated knowledge appear to explain differences between integrated and de-integrated stages of production. In-house portfolio managers appear to be relatively less (more) reliant on tacit (encapsulated) knowledge than external portfolio subadvisors. Second, the more analytically intense the management of a portfolio of investments as measured by increasing (decreasing) relative reliance on tacit (encapsulated) knowledge, the greater the probability of an inter-firm boundary between the portfolio manager and the mutual fund management firm.

In the mutual fund industry, the evidence suggests greater outsourcing of more specialized categories of funds managed with greater relative reliance on tacit knowledge, and practically exclusive in-house management of ordinary money market funds relying relatively more on encapsulated knowledge. This may suggest that larger firms focused on 


\section{KNOWLEDGE-BASED VERTICAL DE-INTEGRATION}

economies of scale and distribution (i.e., mutual fund management firms) may find it expedient to expand their product offering by outsourcing production that is relatively more reliant on tacit knowledge (i.e., contracting with sub-advisory portfolio managers). It may also suggest that as industries evolve over time and their value chains lengthen, it is more cost-effective to retain in-house those functions that tend to be more generic, systematized, and reliant on encapsulated knowledge while outsourcing those that tend to be more unique, specialized and reliant on tacit knowledge.

\section{DISCUSSION}

\section{Contribution}

This paper extends existing research on the knowledge-based view of the firm with three important contributions. First, it built upon refinements of a number of recent survey instruments for measuring organizational knowledge (Choi, Lee, 2003; Fey, Birkinshaw, 2005; Leiponen, 2003; McEvily, Chakravarthy, 2002; Simonin, 1999; Subramaniam, Venkatraman, 2001). The measurement of different classifications of knowledge was accomplished through the collection of relative reliance on these classifications from six different perspectives (van den Berg, 2011, 2013).

Secondly, the analysis of survey results suggested that differences in the knowledge relied upon in production may effectively be measured between adjacent stages of production. The measurement of relative reliance on tacit knowledge and especially encapsulated knowledge proved very reliable, while the measurement of relative reliance on codified knowledge exhibited insufficient reliability. 


\section{KNOWLEDGE-BASED VERTICAL DE-INTEGRATION}

The third, and perhaps most valuable, contribution of this paper is that it presents evidence that relates reliance on tacit and encapsulated knowledge to the presence or absence of an inter-firm boundary. A stage of production with a relatively high (low) reliance on tacit (encapsulated) knowledge was found to be more likely de-integrated from an adjacent stage than if such a stage was less (more) reliant on tacit (encapsulated) knowledge. Arguably, these findings add definition to the analytic intensity of security valuation that, according to Cashman and Deli (2009), serves as the basis for variation in degree of vertical integration of mutual funds.

\section{Limitations}

There is an implied assumption that a portfolio manager's relative reliance on tacit and encapsulated knowledge does not vary between the funds she or he manages. This assumption is questionable, especially in the case of a portfolio manager responsible for funds requiring the application of more than one investment policy. Evidence not presented here suggests that relative reliance on encapsulated knowledge is related to the portfolio management strategy being applied, and a cursory review of the mutual funds suggests that a number of portfolio managers managed funds with different strategies.

For the multi-managed mutual funds, the knowledge-based measures of the portfolio managers identified with the mutual fund were averaged and then entered. Some multi-managed funds had only one respondent portfolio manager, many had two, and one had five. This process introduced two potential inaccuracies. First, in the cases where less than all of a mutual fund's portfolio managers are surveyed, the knowledge-based measurements of the non-respondent portfolio managers are excluded from consideration. The implied assumption is that non-respondent portfolio managers' average relative 


\section{KNOWLEDGE-BASED VERTICAL DE-INTEGRATION}

reliance on tacit and encapsulated knowledge is equal to the average of those who responded.

Secondly, simply averaging the knowledge-based measures of the portfolio managers assumes that they are all equally influential in the management of a multimanaged mutual fund. This assumption implies that disproportionate influence does not exist between a team of portfolio managers of a multi-managed fund. The implied assumption limits the accuracy of the knowledge-based measures, unless the assets of a fund are purposefully proportionately managed.

The measurements of relative reliance on tacit, codified, and encapsulated knowledge were not based on direct observations, but were self-reported. Measurement error entered this research because a different individual reported each participant's responses. It would be preferable in future research if measurements could be made more consistent by collecting them directly using a single external observer.

Since all these limitations conspired against the results obtained, the findings presented in this paper are all the more surprising.

\section{Future Research}

The findings presented here suggest that subsequent research be undertaken to relate organizational structures arranged according to knowledge-based factors to organizational performance. This research should seek to determine if organizational structures that most strongly fit the model offered in this paper differ in performance from those that most strongly refute the model. This would lend strength to the position that organizing along knowledge-based factors is something managers should be considering when making boundary decisions. 


\section{KNOWLEDGE-BASED VERTICAL DE-INTEGRATION}

Since this research focused on discrete inter-firm boundaries, it was beyond the scope of this research to assess multi-managed funds with mixed affiliation (multiple portfolio managers, some in-house, some external to the mutual fund management firm). Future research could explore these hybrid governance modes of portfolio management, perhaps building on the organizational structure coding used by Csaszar (2012).

Future research may also test the generalizability of this study in related industries represented by the NAICS code 5239 - Other Financial Investment Activities, since these share many of the attributes of the population sampled for this research. With some exceptions ${ }^{4}$, this industry group includes establishments primarily engaged in, or acting as agents in, the purchase and sale of financial contracts, or providing investment services such as portfolio management, investment advice, and trust, fiduciary, and custody services.

Research may also extend into industry groups that may not quickly come to mind when discussing "knowledge-based" industries. Industries heavily reliant on material resources in their production processes could be surprisingly amenable to study, since knowledge may be considered a necessary dimension of every production process (Lewin, Phelan, 2000). Furthermore, use such industry groups could provide fertile areas for testing the interplay of knowledge production and governance costs, given that contracting between external portfolio managers (sub-advisors) and mutual fund management firms leaves little room for opportunism (i.e., entails low governance costs).

\footnotetext{
${ }^{4}$ Exceptions include investment bankers, securities dealers, commodity contracts dealers, securities brokerages, commodity contracts brokerages, securities exchanges, and commodity exchanges.
} 


\section{KNOWLEDGE-BASED VERTICAL DE-INTEGRATION}

Another avenue of research worth pursuing involves the observation that risk and returns to de-integrated mutual funds are generally higher than those for integrated mutual funds. It may be that reliance on codified and/or encapsulated knowledge reduces both returns and risk, while reliance on tacit knowledge increases both. If that is the case, it could have implications for many types of production processes outside of the mutual fund industry.

\section{Managerial Implications}

The theory and evidence presented in this research suggest that managers may be setting inter-firm boundaries based, unintentionally, on differences in knowledge-based factor intensities between adjacent stages of production. Managers may be finding it difficult or cost-prohibitive to integrate, within a single firm, a stage of production that is predominantly reliant on tacit knowledge (knowledge that remains resident in the human mind). This may lead them to more likely outsource such production, creating an inter-firm boundary, than if such a stage of production were relatively more reliant on encapsulated knowledge (for example, knowledge embedded in the functionality and design of a software platform).

The survey methodology used in this research may provide a starting point for the collection of data regarding knowledge-based factors of production. While measuring absolute values of knowledge-based factors may be elusive (Down, 2000), relative measurements may provide an adequate alternative. Managers may find that an awareness

of the relative magnitudes of knowledge-based factors used in production processes can be a supplemental instrument for determining when to vertically integrate or de-integrate adjacent stages along a value chain. This study makes no claim to comprehensiveness in 


\section{KNOWLEDGE-BASED VERTICAL DE-INTEGRATION}

weighing all factors to be considered in making decisions regarding vertical integration, but it offers a perspective that may prove to be valuable to managers charged with the responsibility of making these decisions. 


\section{KNOWLEDGE-BASED VERTICAL DE-INTEGRATION}

\section{REFERENCES}

Securities Act. R.S.O. 1990. 2007.

Anderson E. 1985. The Salesperson as outside Agent or Employee: A Transaction Cost Analysis. Marketing Science 4 (3): 234-254.

Argyres N. 1996. Evidence on the Role of Firm Capabilities in Vertical Integration Decisions. Strategic Management Journal 17 (2): 129-150.

Balakrishnan S, Wernerfelt B. 1986. Technical Change, Competition and Vertical Integration. Strategic Management Journal 7 (4): 347-359.

Balconi M. 2002. Tacitness, codification of technological knowledge and the organization of industry. Research Policy 31 (3): 357-379.

Balconi M, Pozzali A, Viale R. 2007. The "codification debate" revisited: a conceptual framework to analyze the role of tacit knowledge in economics. Industrial and Corporate Change 16 (5): 823-849.

Becker GS, Murphy KM. 1992. The Division of Labor, Coordination Costs, and Knowledge. Quarterly Journal of Economics 107 (4): 1137-1160.

Boisot MH. 1998. Knowledge Assets: Securing Competitive Advantage in the Information Economy, Oxford University Press: Oxford

Cashman G, Deli D. 2009. Locating Decision Rights: Evidence from the Mutual Fund Industry. Journal of Financial Markets 12 (4): 645-671.

Choi B, Lee H. 2003. An Empirical Investigation of KM Styles and their Effect on Corporate Performance. Information \& Management 40 (5): 403-417.

Coase RH. 1937. The Nature of the Firm. Economica 4 (16): 386-405.

Cohen J. 1988. Statistical Power Analysis for the Behavioral Sciences, Lawrence Erlbaum Associates: Hillsdale

Cohen J. 1992. A Power Primer. Psychological Bulletin 112 (1): 155-159.

Cottle S, Murray RF, Block FE. 1988. Graham and Dodd's Security Analysis, McGrawHill: Baskerville

Csaszar FA. 2012. Organizational Structure as a Determinant of Performance: Evidence from Mutual Funds. Strategic Management Journal 33 (6): 611-632.

Dean JWJ, Sharfman MP. 1996. Does Decision Process Matter? A Study of Strategic Decision-Making Effectiveness. Academy of Management Journal 39 (2): 368-396. 


\section{KNOWLEDGE-BASED VERTICAL DE-INTEGRATION}

Demsetz H. 1988. Ownership, Control, and the Firm, Basil Blackwell Ltd.: Oxford

Demsetz H. 1991. The Theory of the Firm Revisited. In The Nature of the Firm: Origins, Evolution, and Development, Williamson OE, Winter SG (ed). Oxford University Press: New York

Dosi G. 1982. Technological Paradigms and Technological Trajectories: A Suggested Interpretation of the Determinants and Directions of Technical Change. Research Policy 11 (3): 147-162.

Down J. 2000. Tacit Knowledge in Professional Practice: Researcher and Practitioner Perspectives. (Book Review). Administrative Science Quarterly 45 (1): 170.

Farnsworth H, Taylor J. 2006. Evidence on the Compensation of Portfolio Managers. Journal of Financial Research 29 (3): 305-324.

Faul F, Erdfelder E, Lang A-G, Buchner A. 2007. G*Power 3: A flexible statistical power analysis program for the social, behavioral, and biomedical sciences. Behavior Research Methods 39: 175-191.

Fey CF, Birkinshaw J. 2005. External Sources of Knowledge, Governance Mode, and R\&D Performance. Journal of Management 31 (4): 597-621.

Gorga É. 2007. Knowledge Inputs, Legal Institutions and Firm Structure: Towards a Knowledge-Based Theory of the Firm. Northwestern University Law Review 101 (3): 1123 1206.

Grant RM. 2002. The Knowledge-Based View of the Firm. In The Strategic Management of Intellectual Capital and Organizational Knowledge, Choo CW, Bontis N (ed). Oxford University Press: Oxford

Hoetker G. 2006. Do Modular Products Lead to Modular Organizations. Strategic Management Journal 27 (6): 501-518.

Jacobides MG, Hitt LM. 2005. Losing Sight of the Forest for the Trees?: Productive Capabilities and Gains from Trade as Drivers of Vertical Scope. Strategic Management Journal 26 (13): 1209-1227.

Jensen MC, Meckling WH. 1996. Specific and General Knowledge, and Organizational Structure. In Knowledge Management and Organizational Design, Myers PS (ed). Butterworth-Heinemann: Boston

Joskow P. 1987. Contract duration and relationship-specific investments: Empirical evidence from coal markets. American Economic Review 77 (1): 168-185. 


\section{KNOWLEDGE-BASED VERTICAL DE-INTEGRATION}

Khorana A, Servaes H, Tufano P. 2009. Mutual Fund Fees Around the World. The Review of Financial Studies 22 (3): 1279-1310.

Langlois RN. 2001. Knowledge, Consumption, and Endogenous Growth. Journal of Evolutionary Economics 11 (1): 77-93.

Langlois RN, Foss NJ. 1999. Capabilities and Governance: the Rebirth of Production in the Theory of Economic Organization. Kyklos 52 (2): 201-208.

Lawrence PR, Lorsch JW. 1967. Differentiation and Integration in Complex Organizations. Administrative Science Quarterly 12 (1): 1-47.

Lewin P, Phelan SE. 2000. An Austrian Theory of the Firm. Review of Austrian Economics 13 (1): 59-79.

Mayer KJ, Salomon RM. 2006. Capabilities, Contractual Hazards, and Governance: Integrating Resource-Based and Transaction Cost Perspectives. Academy of Management Journal 49 (5): 942-959.

McEvily SK, Chakravarthy B. 2002. The Persistence of Knowledge-Based Advantage: An Empirical Test for Product Performance and Technological Knowledge. Strategic Management Journal 23 (4): 285-305.

Miller CC. 2008. Decisional Comprehensiveness and Firm Performance: Toward a More Complete Understanding. Journal of Behavioral Decision Making 21 (5): 598-620.

Monteverde K, Teece DJ. 1982. Supplier Switching Costs and Vertical Integration. Bell Journal of Economics 13 (1): 206-213.

Pfaffmann E. 2000. Knowledge Maturity, Modularity, and the Vertical Boundaries of the Firm. In Competence, Governance, and Entrepreneurship - Advances in Economic Strategy Research, Mahnke V (ed). Oxford University Press: Oxford

Pisano GP. 1990. The R\&D Boundaries of the Firm: An Empirical Analysis. Administrative Science Quarterly 35 (1): 153-176.

Polanyi M. 1969. Knowing and Being: Essays by Michael Polanyi, Routledge: London

Prahalad CK, Bettis RA. 1986. The Dominant Logic: A New Linkage Between Diversity and Performance. Strategic Management Journal 7 (6): 485-502.

Robertson TS, Gatignon H. 1998. Technology development mode: A transaction cost conceptualization. Strategic Management Journal 19 (6): 515-531.

Simon HA. 1999. The Many Shapes of Knowledge. Revue d'Économie Industrielle 88 (2e trimestre): 23-39. 


\section{KNOWLEDGE-BASED VERTICAL DE-INTEGRATION}

Simonin BL. 1999. Ambiguity and the Process of Knowledge Transfer in Strategic Alliances. Strategic Management Journal 20 (7): 595-623.

Spender J-C. 1996. Making Knowledge the Basis of a Dynamic Theory of the Firm. Strategic Management Journal 17 (Special Issue: Knowledge and the Firm): 45-62.

Subramaniam M, Venkatraman N. 2001. Determinants of Transnational New Product Development Capability: Testing the Influence of Transferring and Deploying Tacit Overseas Knowledge. Strategic Management Journal 22: 359-378.

Szulanski G. 1996. Exploring Internal Stickness: Impediments to the Transfer of Best Practice within the Firm. Strategic Management Journal 17 (Winter Special Issue): 27-43.

Tufano P, Sevick M. 1997. Board structure and fee-setting in the U.S. mutual fund industry. Journal of Financial Economics 46 (3): 321-355.

van den Berg HA. 2011. Vertical integration: applying an economic calculus to knowledge. International Journal of Learning and Intellectual Capital 8 (4): 399-417.

van den Berg HA. 2013. Three shapes of organisational knowledge. Journal of Knowledge Management 17 (2): 159-174.

von Hippel E. 1994. "Sticky Information" and the Locus of Problem Solving: Implications for Innovation. Management Science 40 (4): 429-439.

Walker G, Weber D. 1984. A Transaction Cost Approach to Make-or-Buy Decisions. Administrative Science Quarterly 29 (3): 373-391.

Williamson OE. 1975. Markets and Hierarchies: Analysis and Antitrust Implications: A Study in the Economics of Internal Organization, Free Press: New York

Williamson OE. 1979. Transaction-cost economics: The governance of contractual relations. Journal of Law and Economics 22: 233-261.

Williamson OE. 1981. The Economics of Organization: The Transaction Cost Approach. American Journal of Sociology 87 (3): 548-577.

Zander U, Kogut B. 1995. Knowledge and the Speed of the Transfer and Imitation of Organizational Capabilities: An Empirical Test. Organization Science 6 (1): 76-92.

Zellner C. 2003. The economic effects of basic research: evidence for embodied knowledge transfer via scientists' migration. Research Policy 32 (10): 1881-1895. 
TABLE 1

Difference in probability of de-integration between foreign equity and domestic equity mutual funds

\begin{tabular}{|c|c|c|c|c|c|c|c|c|c|}
\hline & \multicolumn{3}{|c|}{$\begin{array}{l}\text { Foreign equity mutual } \\
\text { funds }\end{array}$} & \multicolumn{3}{|c|}{$\begin{array}{l}\text { Domestic equity } \\
\text { mutual funds }\end{array}$} & \multirow[b]{2}{*}{ t-statistic } & \multirow[b]{2}{*}{$\begin{array}{l}\text { Cohen's 'd' } \\
\text { (effect size) }\end{array}$} & \multirow[b]{2}{*}{$\begin{array}{l}\text { Power } \\
\text { of the } \\
\text { test }\end{array}$} \\
\hline & Mean & S.D. & $\mathrm{N}$ & Mean & S.D. & $\mathrm{N}$ & & & \\
\hline $\begin{array}{l}\text { Probability of de- } \\
\text { integrated } \\
\text { organizational } \\
\text { structure } \\
\qquad * p<0.05 \\
\quad * * p<0.01 \\
\quad * * * p<0.001\end{array}$ & 0.52 & 0.500 & 1138 & 0.39 & .488 & 842 & $5.721 * * *$ & $\begin{array}{l}0.26 \text { (small } \\
\text { to medium) }\end{array}$ & $99 \%$ \\
\hline
\end{tabular}

TABLE 2

Difference in probability of de-integration between domestic equity and fixed income mutual funds

\begin{tabular}{|c|c|c|c|c|c|c|c|c|c|}
\hline & \multicolumn{3}{|c|}{$\begin{array}{l}\text { Domestic equity } \\
\text { mutual funds }\end{array}$} & \multicolumn{3}{|c|}{$\begin{array}{l}\text { Fixed income } \\
\text { mutual funds }\end{array}$} & \multirow[b]{2}{*}{ t-statistic } & \multirow[b]{2}{*}{$\begin{array}{l}\text { Cohen's 'd' } \\
\text { (effect size) }\end{array}$} & \multirow[b]{2}{*}{$\begin{array}{l}\text { Power } \\
\text { of the } \\
\text { test }\end{array}$} \\
\hline & Mean & S.D. & $\mathrm{N}$ & Mean & S.D. & $\mathrm{N}$ & & & \\
\hline $\begin{array}{l}\text { Probability of de- } \\
\text { integrated } \\
\text { organizational } \\
\text { structure } \\
\quad * n<005\end{array}$ & 0.39 & 0.488 & 842 & 0.19 & 0.396 & 598 & $8.184 * * *$ & $\begin{array}{l}0.45 \\
\text { (small to } \\
\text { medium) }\end{array}$ & $\sim 100 \%$ \\
\hline
\end{tabular}

$\begin{aligned} * p & <0.05 \\ * * p & <0.01 \\ * * * p & <0.001\end{aligned}$ 
TABLE 3

Structure and management mode of mutual funds for which estimates of portfolio managers' relative reliance on knowledge-based factors of production are available

\begin{tabular}{llll}
\hline & Single-managed (One) & Multi-managed (> One) & Total \\
\cline { 2 - 4 } Integrated & $140(32.6 \%)$ & $179(41.6 \%)$ & $319(74.2 \%)$ \\
De-integrated & $31(7.2 \%)$ & $80(18.6 \%)$ & $111(25.8 \%)$ \\
Total & $171(39.8 \%)$ & $259(60.2 \%)$ & 430 \\
\hline Chi square $=8.756$ & & & \\
df $=1$ & & & \\
$\mathrm{p}<0.01$ & & &
\end{tabular}

TABLE 4

Difference in relative reliance on tacit and encapsulated knowledge between foreign equity and domestic equity mutual funds

\begin{tabular}{|c|c|c|c|c|c|c|c|c|c|}
\hline & \multicolumn{3}{|c|}{$\begin{array}{l}\text { Foreign equity mutual } \\
\text { funds }\end{array}$} & \multicolumn{3}{|c|}{$\begin{array}{l}\text { Domestic equity } \\
\text { mutual funds }\end{array}$} & \multirow[b]{2}{*}{ t-statistic } & \multirow[b]{2}{*}{$\begin{array}{l}\text { Cohen's 'd' } \\
\text { (effect size) }\end{array}$} & \multirow[b]{2}{*}{$\begin{array}{l}\text { Power } \\
\text { of the } \\
\text { test }\end{array}$} \\
\hline & Mean & S.D. & $\mathrm{N}$ & Mean & S.D. & $\mathrm{N}$ & & & \\
\hline $\begin{array}{l}\text { Relative reliance } \\
\text { on tacit } \\
\text { knowledge } \\
\text { Relative reliance } \\
\text { on encapsulated } \\
\text { knowledge }\end{array}$ & -0.723 & 0.968 & 117 & -0.033 & 0.713 & 120 & $-6.093 * * *$ & $\begin{array}{l}0.71 \\
\text { (medium to } \\
\text { large) } \\
0.79 \\
\text { (medium to } \\
\text { large) }\end{array}$ & $\sim 100 \%$ \\
\hline
\end{tabular}

$* p<0.05$

$* * p<0.01$

$* * * p<0.001$ 
TABLE 5

Difference in relative reliance on tacit and encapsulated knowledge between domestic equity and fixed income mutual funds

\begin{tabular}{l|lll|lll|llll}
\hline & \multicolumn{7}{|l}{$\begin{array}{l}\text { Domestic equity } \\
\text { mutual funds }\end{array}$} & \multicolumn{7}{l}{$\begin{array}{l}\text { Fixed income mutual } \\
\text { funds }\end{array}$} \\
& Mean & S.D. & $\mathrm{N}$ & Mean & S.D. & $\mathrm{N}$ & t-statistic & \begin{tabular}{l} 
Cohen's 'd' $\begin{array}{l}\text { Power } \\
\text { (effect size) } \\
\text { of the } \\
\text { test }\end{array}$ \\
\hline $\begin{array}{l}\text { Relative reliance } \\
\text { on tacit } \\
\text { knowledge }\end{array}$
\end{tabular} \\
$\begin{array}{l}\text { Relative reliance } \\
\text { on encapsulated } \\
\text { knowledge }\end{array}$ & -0.033 & 0.713 & 120 & -0.347 & 0.479 & 74 & $3.673^{* * *}$ & $\begin{array}{l}0.52 \\
\text { (medium) }\end{array}$ & $56 \%$ \\
\hline
\end{tabular}

$* p<0.05$

$* * p<0.01$

$* * * p<0.001$

TABLE 6

Logistic regression estimates for a de-integrated organizational structure using investment regions $\mathbf{s}^{\mathrm{a}, \mathrm{b}, \mathrm{c}}$

\begin{tabular}{lll}
\hline Independent variables & Model I & Model II \\
\hline \multirow{2}{*}{ Constant } & $-1.535^{* * *}$ & $-2.338^{* * *}$ \\
& $(0.295)$ & $(0.358)$ \\
Investment region is Canada & 0.280 & $0.918^{*}$ \\
& $(0.332)$ & $(0.371)$ \\
Investment region is Europe & $3.240^{* * *}$ & $3.615^{* * *}$ \\
& $(0.823)$ & $(0.823)$ \\
Investment region is Global & $0.892^{*}$ & $1.146^{* *}$ \\
Relative reliance on tacit knowledge & $(0.369)$ & $(0.369)$ \\
Relative reliance on encapsulated knowledge & & -0.388 \\
$N$ & & $(0.244)$ \\
-2 Log likelihood & & $-1.260^{* * *}$ \\
Improvement in -2 Log likelihood $^{\mathrm{c}}$ & & $(0.246)$ \\
\hline
\end{tabular}

${ }^{\text {a }}$ Positive coefficients indicate a greater probability of de-integration. Standard errors are in brackets.

b $* p<0.05$

$* * p<0.01$

$* * * p<0.001$

${ }^{c}-2$ Log likelihood for the null model was 491.148. Degrees of freedom are in brackets. 
KNOWLEDGE-BASED VERTICAL DE-INTEGRATION

TABLE 7

Logistic regression estimates for a de-integrated organizational structure using Cashman and Deli's (2009) categories of analytic intensity ${ }^{\text {a,b,c }}$

\begin{tabular}{|c|c|c|}
\hline Independent variables & Model III & Model IV \\
\hline Constant & $\begin{array}{l}-1.455^{* * *} \\
(0.297)\end{array}$ & $\begin{array}{l}-1.238 * * * \\
(0.303)\end{array}$ \\
\hline Foreign Equity relative to Fixed Income & $\begin{array}{l}1.064 * * \\
(0.353)\end{array}$ & $\begin{array}{l}0.533 \\
(0.399)\end{array}$ \\
\hline Domestic Equity relative to Fixed Income & $\begin{array}{l}-0.279 \\
(0.392)\end{array}$ & $\begin{array}{l}-0.487 \\
(0.402)\end{array}$ \\
\hline Relative reliance on tacit knowledge & & $\begin{array}{l}0.577 * * \\
(0.179)\end{array}$ \\
\hline$N$ & 308 & 308 \\
\hline-2 Log likelihood & $327.002(2)^{* * *}$ & $316.625(3)^{* * *}$ \\
\hline Improvement in -2 Log likelihood $^{c}$ & $21.576(2)^{* * *}$ & $10.377(1)^{* *}$ \\
\hline
\end{tabular}

${ }^{\mathrm{a}}$ Positive coefficients indicate a greater probability of de-integration. Standard errors are in brackets.

b $* p<0.05$

$* * p<0.01$

$* * * p<0.001$

${ }^{c}-2$ Log likelihood for the null model was 348.578. Degrees of freedom are in brackets. 